\title{
Effect of feeding fermented mixture of cassava pulp and Moringa oleifera leaf meal on immune responses, antioxidative status, biochemistry indices, and intestinal ecology of broilers
}

\author{
Sugiharto Sugiharto, Endang Widiastuti, Isroli Isroli, Turrini Yudiarti, Tri A. Sartono and Hanny I. Wahyuni \\ Department of Animal Science, Faculty of Animal and Agricultural Sciences, Diponegoro University, Semarang, \\ Central Java, Indonesia. \\ Corresponding author: Sugiharto Sugiharto, e-mail: sgh_undip@yahoo.co.id \\ Co-authors: EW: endwidia@yahoo.co.id, II: isroliundip02@yahoo.com, TY: tyudiarti@yahoo.co.id, \\ TAS: tasartono78@gmail.com, HIW: hihannyiw123@gmail.com \\ Received: 07-10-2019, Accepted: 17-01-2020, Published online: 28-02-2020
}

doi: www.doi.org/10.14202/vetworld.2020.392-399 How to cite this article: Sugiharto S, Widiastuti E, Isroli I, Yudiarti T, Sartono TA, Wahyuni HI (2020) Effect of feeding fermented mixture of cassava pulp and Moringa oleifera leaf meal on immune responses, antioxidative status, biochemistry indices, and intestinal ecology of broilers, Veterinary World, 13(2): 392-399.

\begin{abstract}
Aim: The study investigated the effect of feeding fermented mixture of cassava pulp and Moringa oleifera leaf meal (FCPMO) on the immune responses, antioxidative status, biochemical parameters, and intestinal ecology of broiler chickens.

Materials and Methods: Four hundred Lohmann broiler chickens were distributed to four groups of diets including CONT (corn-soybean-based feed with no additive), BACI (corn-soybean-based diet supplemented with $0.1 \%$ zinc bacitracin), FERM (diet containing 20\% FCPMO), and FERB (diet containing 20\% FCPMO and added with $0.1 \%$ Bacillus subtilis). At days 4,14 , and 19, the chicks were vaccinated using commercial Newcastle disease-infectious bursal disease (ND-IBD), IBD, and ND vaccines, respectively. At day 35, blood was sampled and digesta was obtained from the ileum and caecum. Furthermore, the duodenal segment was obtained.

Results: The BACI, FERM, and FERB groups had higher $(\mathrm{p}<0.05)$ serum superoxide dismutase activity than control. The malondialdehyde was lower $(\mathrm{p}=0.07)$ in BACI, FERM, and FERB than that in CONT. The BACI and FERM had lower $(p<0.05)$ leukocytes and lymphocytes than CONT. The hemoglobin, erythrocytes, and hematocrit were lower $(p<0.05)$ in BACI and FERM than those in CONT and FERB. Serum total triglyceride was lower $(p<0.05)$ in FERM and FERB than that in CONT. The FERM and FERB had higher $(p<0.05)$ albumin levels. Serum globulin level was lower $(p<0.05)$ in FERB than that in BACI, but did not differ from that in CONT and FERM. The numbers of coliform, lactose-negative-enterobacteria and enterobacteria were lower $(p<0.05)$ in FERB than that in other treatment groups. Crypt depth $(C D)$ was higher $(p<0.05)$ in FERM, while the villi height to CD ratio was lower $(\mathrm{p}<0.05)$ in FERM than that in CONT and FERB. The treatments showed no effect $(\mathrm{p}>0.05)$ on cecal volatile fatty acids production.
\end{abstract}

Conclusion: Feeding FCPMO improved immune responses, antioxidative status, and physiological conditions, but had less effect on the intestinal ecology of broilers.

Keywords: antioxidant, broiler, fermented feed, health.

\section{Introduction}

Feed efficiency is a critical factor for sustainable broiler enterprise worldwide. This is because feed accounts for more than $70 \%$ of the whole broiler production cost. Among the feed constituents, dietary energy sources (e.g., maize) occupy the major proportion of the broiler rations and thereby greatly determine the economics of the broiler industry. The continuous increase and the fluctuation in prices of the dietary energy sources have encouraged some farmers and broiler industries to exploit poor quality energy source feedstuffs. This practice may, however, result in less feed consumption, retarded growth rate, poor

Copyright: Sugiharto, et al. Open Access. This article is distributed under the terms of the Creative Commons Attribution 4.0 International License (http://creativecommons.org/licenses/ by/4.0/), which permits unrestricted use, distribution, and reproduction in any medium, provided you give appropriate credit to the original author(s) and the source, provide a link to the Creative Commons license, and indicate if changes were made. The Creative Commons Public Domain Dedication waiver (http:// creativecommons.org/publicdomain/zero/1.0/) applies to the data made available in this article, unless otherwise stated. meat quality, and thus impaired overall economic performance [1]. Among the poor quality dietary energy sources, cassava pulp that is a by-product of tapioca production has widely been incorporated in broiler rations to reduce the proportion of maize partly. Yet, the extent of inclusion of cassava pulp is limited at a maximum of $8 \%$ from the total diets, as the greater extent of incorporation can compromise the growth and well-being of broilers [2]. To improve the nutritional qualities and hence enhance the dietary incorporation levels, fermentation has been applied on cassava pulp [3,4]. In most circumstances, urea may also be added in conjunction with the fermentation to elevate further the content of protein in cassava pulp $[5,6]$. Such urea supplementation can, however, harm the kidney and liver of the chickens particularly when the bioconversion of urea into microbial biomass protein is not completed during the fermentation $[7,8]$. Any alternative to further elevate the protein concentration of the cassava pulp based-fermented product is therefore beneficial. 
The use of leaf meals as a source of protein in broiler diets has become a beneficial means to alleviate the cost of feed in poultry production. Apart from their high protein content, in general, leaf meals contain various anti-nutritional factors and toxins [9]. These latter properties may impair nutrient digestibility and utilization and also jeopardize the health of chickens. Indeed, fermentation has been documented to reduce the contents of anti-nutrition and toxins in the substrates $[9,10]$. In this regard, fermentation seems to be worthwhile for maximizing the utilization of dietary leaf meals by the chickens [8]. In this present study, Moringa oleifera leaf meal was mixed with cassava pulp before fermentation. Considering its high protein content $[8,11]$, the $M$. oleifera leaf meal supplementation was expected to safely upgrade the protein content of cassava pulp, which was usually contributed by urea. A recent study revealed that feeding fermented feed was attributed to the improved immune responses, physiological conditions, and intestinal morphology and ecosystem of broiler chickens. Feeding such a diet has also been documented to improve the antioxidative status of broilers $[9,10]$. Besides being rich in protein, M. oleifera leaf meal has been documented to contain a myriad of phytochemical properties (e.g., antimicrobial and antioxidant agents) [11] that can promote the health of broiler chickens. In this study, the filamentous fungus Chrysonilia crassa was employed as the fermentation starter considering its fibrinolytic activity that can degrade the complex fiber into simple sugar [12]. Furthermore, the fungus exhibited probiotic properties [13], which may exert a beneficial impact on the health condition of broilers. Overall, it was expected that the combined effects of fermented feed, $M$. oleifera leaf meal and the fungus $C$. crassa would result in improved immune responses, antioxidative status, physiological conditions, and intestinal ecology of broiler chickens.

This study aimed to investigate the effect of feeding fermented mixture of cassava pulp and M. oleifera leaf meal (FCPMO) on the immune responses, antioxidative status, biochemistry indices, and intestinal ecology of broilers.

\section{Materials and Methods}

\section{Ethical approval}

The current experiment was approved by the Animal Ethics Committee of the Faculty of Animal and Agricultural Sciences, Diponegoro University, Indonesia and conducted in compliance with the standard procedures of raising livestock mentioned in the law of the Republic of Indonesia number 18, 2009, regarding animal husbandry and health.

\section{Production of fermented mixture of cassava pulp and M. oleifera leaf meal}

The production of the FCPMO was preceded by the production of the fermentation starter. It began with the rejuvenation of the fungus $C$. crassa from the stored culture (preserved on potato dextrose agar
$[\mathrm{PDA}]$ at $\left.4^{\circ} \mathrm{C}\right)$. The rejuvenated fungi were then aerobically re-cultured on PDA for $48 \mathrm{~h}$ at $38^{\circ} \mathrm{C}$. The spores of fungi were collected using $10 \mathrm{~mL}$ autoclaved distilled water. To produce the fermentation starter, $100 \mathrm{~g}$ of the used rice (purchased from the traditional market in Semarang) was cleaned and immersed in tap water for about $1 \mathrm{~h}$. It was then steamed for $1 \mathrm{~h}$ and left on the tray until cool. The steamed used rice was subsequently inoculated with the fungal spore suspension $(10 \mathrm{~mL})$ as prepared above and aerobically incubated at room temperature for $48 \mathrm{~h}$. The product from the latter process was sun-dried, milled, and eventually sieved before being used as a fermentation starter. Fungal colony enumeration (based on the plate count method) showed that the fermentation starter contained $>1 \times 10^{8}$ colony-forming unit/g of $C$. crassa colonies.

To produce the FCPMO, the dried cassava pulp containing $\pm 12 \%$ of water content (purchased from the local supplier in Boyolali Regency, Central Java Province) was steamed for $1 \mathrm{~h}$ and permitted to cool thereafter. The $M$. oleifera leaf meal was prepared from the $M$. oleifera leaves collected from the gardens surrounding the university. The $M$. oleifera leaves were collected from March to May 2019. The M. oleifera leaves were spread, air-dried at room temperature and ground down into meal before use. For the production of the FCPMO, the steamed cassava pulp $(60 \mathrm{~g})$ was blended with $M$. oleifera leaf meal (35 g) and immediately inoculated with $5 \mathrm{~g}$ of fermentation starter (as prepared above). To obtain the moisture content of about $40 \%$, the inoculated mixture was then poured with the sterilized distilled water $(100 \mathrm{~mL})$. The culture was aerobically incubated at about $25^{\circ} \mathrm{C}$ (room temperature), and after $72 \mathrm{~h}$, the FCPMO was sundried. After being taken for proximate analysis [14], the fermented product was stored at room temperature until use. The FCPMO contained $8.75 \%$ moisture, $17.6 \%$ crude protein, $4.41 \%$ crude fat, $9.01 \%$ crude fiber, and $10.1 \%$ ash, while cassava pulp contained $11.0 \%$ moisture, $2.24 \%$ crude protein, $0.91 \%$ crude fat, $31.8 \%$ crude fiber, and $3.65 \%$ ash. $M$. oleifera leaf meal contained $11.1 \%$ moisture, $29.9 \%$ crude protein, $5.38 \%$ crude fat, $13.2 \%$ crude fiber, and $12.6 \%$ ash.

\section{In vivo trial}

Four hundred Lohmann broiler meat chickens were raised according to the commercial circumstances within the first 7 days. At day 8 , the birds were allotted to four groups of diets, i.e. CONT (corn-soybean-based feed with no additive), BACI (corn-soybean-based diet administrated with $0.1 \%$ zinc bacitracin/in-feed antibiotic), FERM (diet with $20 \%$ of the FCPMO), and FERB (diet with $20 \%$ of the FCPMO and added with $0.1 \%$ probiotic Bacillus subtilis). Every group of the diet consisted of ten pens/replicates with ten birds per pen. The feeds were offered in mash form as a starter (Table-1) and finisher (Table-2) feed, and were offered ad libitum to all 
Table-1: Constituents and chemical compositions of starter (days 8-21) diets.

\begin{tabular}{lcccc}
\hline \multirow{2}{*}{$\begin{array}{l}\text { Items (\%, unless } \\
\text { otherwise noted) }\end{array}$} & \multicolumn{4}{c}{ Dietary groups } \\
\cline { 2 - 5 } & CONT & BACI & FERM & FERB \\
\hline Yellow maize & 54.8 & 54.8 & 38.5 & 38.5 \\
SBM & 35.7 & 35.7 & 32.3 & 32.3 \\
MBM & 4.70 & 4.70 & 4.25 & 4.25 \\
Soybean oil & 1.55 & 1.55 & 1.75 & 1.75 \\
FCPMO & - & - & 20.0 & 20.0 \\
DL-methionine, 990 g & 0.30 & 0.30 & 0.30 & 0.30 \\
L-Lysine, 780 g & 0.20 & 0.20 & 0.20 & 0.20 \\
Limestone & 0.50 & 0.50 & 0.50 & 0.50 \\
DCP & 1.50 & 1.50 & 1.50 & 1.50 \\
Premix1 & 0.50 & 0.50 & 0.50 & 0.50 \\
Salt & 0.25 & 0.25 & 0.25 & 0.25 \\
Calculated compositions & & & & \\
$\quad$ ME (kcal/kg) & 2900 & 2900 & 2900 & 2900 \\
Crude protein & 22.0 & 22.0 & 22.0 & 22.0 \\
Crude fiber & 5.60 & 5.60 & 6.30 & 6.30 \\
Ca & 1.10 & 1.10 & 1.10 & 1.10 \\
P (available) & 0.70 & 0.70 & 0.70 & 0.70 \\
Lysine & 1.20 & 1.20 & 1.20 & 1.20 \\
Methionine & 0.60 & 0.60 & 0.60 & 0.60 \\
\hline
\end{tabular}

${ }^{1}$ Premix contained (per kg of diet) of Vitamin

A 7750 IU, Vitamin D3 1550 IU, Vitamin E

$1.88 \mathrm{mg}$, Vitamin B1 $1.25 \mathrm{mg}$, Vitamin B2 $3.13 \mathrm{mg}$, Vitamin B6 1.88 mg, Vitamin B12 0.01 mg, Vitamin C $25 \mathrm{mg}$, folic acid $1.50 \mathrm{mg}$, Ca-d-pantothenate $7.5 \mathrm{mg}$, niacin $1.88 \mathrm{mg}$, biotin $0.13 \mathrm{mg}$, BHT $25 \mathrm{mg}$, Co $0.20 \mathrm{mg}$, Cu $4.35 \mathrm{mg}$, Fe $54 \mathrm{mg}, \mathrm{I} 0.45 \mathrm{mg}, \mathrm{Mn} 130 \mathrm{mg}, \mathrm{Zn}$ $86.5 \mathrm{mg}$, Se $0.25 \mathrm{mg}$, L-lysine $80 \mathrm{mg}$, choline chloride $500 \mathrm{mg}$, DL-methionine $900 \mathrm{mg}, \mathrm{CaCO}_{3} 641.5 \mathrm{mg}$, dicalcium phosphate $1500 \mathrm{mg}$. ${ }^{2}$ Metabolizable energy was calculated on the basis of formula (Bolton, 1967) as follow: $40.81\{0.87$ [crude protein +2.25 crude fat+nitrogen+free extract $]+2.5\}$. CONT $=$ Chicks received corn-soybean-based diet without additive, BACI=Chicks received corn-soybean-based diet supplemented with $0.1 \%$ zinc bacitracin, FERM $=$ Chicks received diet containing $20 \%$ of the FCPMO, FERB=Chicks received diet containing $20 \%$ of the FCPMO and supplemented with $0.1 \%$ probiotic $B$. subtilis, $\mathrm{SBM}=$ Soybean meal, $\mathrm{MBM}=$ Meat bone meal, $\mathrm{FCPMO}=$ Fermented mixture of cassava pulp and $M$. oleifera leaf meal, $D C P=$ Dicalcium phosphate, $\mathrm{ME}=$ Metabolizable energy, $B$. subtilis=Bacillus subtilis, M. oleifera=Moringa oleifera

birds. Enzymes, antibiotics, antimolds, antiprotozoal, and anthelmintics were not incorporated in the diets. Through eye route, the chicks were vaccinated using the commercial Newcastle disease-infectious bursal disease (ND-IBD) vaccines on day 4 . The chicks were also vaccinated using the commercial IBD vaccine on day 14 through drinking water. On day 19, the birds were vaccinated again with the commercial ND vaccine through drinking water. Along the period of trial, an opened-sided broiler house was used to raise the chicks. The litter/bedding was prepared from the rice husk. At the final of the experiment (day 35), ten birds from each diet (one bird per pen) were blood sampled (through wing veins) and subsequently slaughtered. The collected blood was placed either in vacutainers with ethylenediaminetetraacetic acid or vacutainers with no anticoagulant (to produce serum). To count the bacterial populations, digesta was obtained from
Table-2: Constituents and chemical compositions of finisher (days 22-35) diets.

\begin{tabular}{lcccc}
\hline \multirow{2}{*}{$\begin{array}{l}\text { Items (\%, unless } \\
\text { otherwise noted) }\end{array}$} & \multicolumn{4}{c}{ Dietary groups } \\
\cline { 2 - 5 } & CONT & BACI & FERM & FERB \\
\hline Yellow maize & 58.5 & 58.5 & 42.4 & 42.4 \\
SBM & 32.7 & 32.7 & 28.8 & 28.8 \\
MBM & 2.35 & 2.35 & 2.25 & 2.25 \\
Soybean oil & 3.25 & 3.25 & 3.35 & 3.35 \\
FCPMO & - & - & 20.0 & 20.0 \\
DL-methionine, 990 g & 0.30 & 0.30 & 0.30 & 0.30 \\
L-Lysine, 780 g & 0.20 & 0.20 & 0.20 & 0.20 \\
Limestone & 0.50 & 0.50 & 0.50 & 0.50 \\
DCP & 1.50 & 1.50 & 1.50 & 1.50 \\
Premix 1 & 0.50 & 0.50 & 0.50 & 0.50 \\
Salt & 0.25 & 0.25 & 0.25 & 0.25 \\
Calculated compositions & & & & \\
$\quad$ ME ${ }^{2}$ (kcal/kg) & 3060 & 3060 & 3060 & 3060 \\
Crude protein & 20.0 & 20.0 & 20.0 & 20.0 \\
Crude fiber & 5.60 & 5.60 & 6.30 & 6.30 \\
Ca & 1.10 & 1.10 & 1.10 & 1.10 \\
P (available) & 0.70 & 0.70 & 0.70 & 0.70 \\
Lysine & 1.20 & 1.20 & 1.20 & 1.20 \\
Methionine & 0.60 & 0.60 & 0.60 & 0.60 \\
\hline
\end{tabular}

${ }^{1}$ Premix contained (per kg of diet) of Vitamin A 7750 IU, Vitamin D3 1550 IU, Vitamin E 1.88 mg, Vitamin B1 $1.25 \mathrm{mg}$, Vitamin B2 $3.13 \mathrm{mg}$, Vitamin B6 1.88 mg, Vitamin B12 0.01 mg, Vitamin C $25 \mathrm{mg}$, folic acid $1.50 \mathrm{mg}$, Ca-d-pantothenate $7.5 \mathrm{mg}$, niacin $1.88 \mathrm{mg}$, biotin $0.13 \mathrm{mg}$, BHT $25 \mathrm{mg}$, Co $0.20 \mathrm{mg}$, Cu 4.35 mg, Fe 54 mg, I 0.45 mg, Mn 130 mg, Zn $86.5 \mathrm{mg}$, Se $0.25 \mathrm{mg}$, L-lysine $80 \mathrm{mg}$, choline chloride $500 \mathrm{mg}$, DL-methionine $900 \mathrm{mg}, \mathrm{CaCO}_{3} 641.5 \mathrm{mg}$, dicalcium phosphate $1500 \mathrm{mg}$. ${ }^{2}$ Metabolizable energy was calculated on the basis of formula (Bolton, 1967) as follow: $40.81\{0.87$ [crude protein +2.25 crude fat+nitrogen+free extract $]+2.5\}$. CONT $=$ Chicks received corn-soybean-based diet without additive, BACI=Chicks received corn-soybean-based diet supplemented with $0.1 \%$ zinc bacitracin, FERM $=$ Chicks received diet containing $20 \%$ of the FCPMO, FERB=Chicks received diet containing $20 \%$ of the FCPMO and supplemented with $0.1 \%$ probiotic $B$. subtilis, SBM=Soybean meal, $\mathrm{MBM}=$ Meat bone meal, $\mathrm{FCPMO}=$ Fermented mixture of cassava pulp and $M$. oleifera leaf meal, $D C P=$ Dicalcium phosphate, $\mathrm{ME}=$ Metabolizable energy. $B$. subtilis=Bacillus subtilis, M. oleifera=Moringa oleifera

the ileum of broilers. Furthermore, the cecal content was obtained for the determination of short-chain fatty acids (SCFA) production in the ceca. For the measurement of villi height and crypt depth (CD), around $2 \mathrm{~cm}$ of the duodenal segment was collected in $10 \%$ neutral formalin buffer solution.

The blood profile of chicks was assessed with a hematology analyzer (Prima Fully-auto Hematology Analyzer, PT. Prima Alkesindo Nusantara, Jakarta, Indonesia). The levels of antibody titers against the ND vaccine in the serum were measured according to the hemagglutination inhibition (HI) test, while the antibody titers against the IBD vaccine were based on the enzyme-linked immunosorbent assay method. The lipid profile (concentrations of total triglyceride, total cholesterol, high-density lipoprotein, as well as low-density lipoprotein) and concentrations of uric acid and creatinine in the serum were measured on the 
basis of the enzymatic colorimetric/color assays. The concentrations of alanine aminotransferase, aspartate aminotransferase, and total protein and albumin in the serum of chicks were measured according to the spectrophotometric/photometric assays. The data on globulin were generated from the serum total protein minus albumin. The aforementioned biochemical assays were run following the protocols from the manufacturer (DiaSys Diagnostic Systems GmbH, Holzheim, Germany). The levels of catalase, malondialdehyde (MDA), and serum superoxide dismutase (SOD) were spectrophotometrically determined with kits (Sigma-Aldrich, St. Louis, USA).

The histologic analysis was conducted using $5 \mu \mathrm{m}$ of duodenal slice dyed with hematoxylin and eosin. The height of villus and depth of crypt were determined using an optical microscope fitted to a digital camera. The five measurements were used to obtain the mean of villi height and CD per chick. The selected bacteria numbers in the ileum of chicks were assigned based on Sugiharto et al. [15] with little changes. The coliform and lactose-negative enterobacteria were counted on MacConkey agar (Merck $\mathrm{KGaA}$, Darmstadt, Germany) as red and colorless colonies after aerobic incubation $\left(38^{\circ} \mathrm{C}, 24 \mathrm{~h}\right)$. The sum of coliform and lactose-negative enterobacteria was considered as Enterobacteriaceae. The same digesta sample was counted for the populations of lactic acid bacteria (LAB). The enumeration was conducted on de Man, Rogosa and Sharpe (MRS; Merck KGaA) agar following anaerobic incubation $\left(38^{\circ} \mathrm{C}, 48 \mathrm{~h}\right)$. The levels of SCFA in the ceca of broilers were measured using gas chromatography based on the conditions explained by Sugiharto et al. [16].

\section{Statistical analysis}

The data collected from the present trial were statistically analyzed with a one-way analysis of variance (SAS Inst. Inc., Cary, NC, USA). The latter analysis was applied to confirm whether there was a difference among the four treatment groups. When the remarkable $(\mathrm{p}<0.05)$ variation existed among the treatment groups, Duncan's multiple range test was then conducted. This post hoc analysis was applied to determine the substantial difference among group means in the analysis of variance.

\section{Results and Discussion}

Feeding fermented feed has usually been associated with improved immune functions in broiler chickens. Sugiharto and Ranjitkar [10] formerly revealed that fermented feed may increase the concentrations of the antibody as well as T cells of broiler chickens. The latter authors further suggested that the LAB contained in the fermented feed may induce the production of cytokines (by immune cells), which are capable of stimulating of broiler's immune responses. Different from the latter report, data in our current study did not show any effect ( $p>0.05)$ of FCPMO on the IBDV and
Table-3: Immune responses and antioxidative status of broiler chickens fed treatment diets.

\begin{tabular}{|c|c|c|c|c|c|c|}
\hline \multirow[t]{2}{*}{ Items } & \multicolumn{4}{|c|}{ Dietary groups } & \multirow[t]{2}{*}{ SE } & \multirow[t]{2}{*}{ p-value } \\
\hline & CONT & BACI & FERM & FERB & & \\
\hline $\begin{array}{l}\text { IBDV } \\
\text { titer (GMT) }\end{array}$ & 11.8 & 11.9 & 11.8 & 11.6 & 8.57 & 0.59 \\
\hline $\begin{array}{l}\text { NDV titer } \\
\text { (Log, GMT) }\end{array}$ & 2.80 & 3.40 & 3.50 & 3.40 & 0.58 & 0.82 \\
\hline $\begin{array}{l}\text { Catalase } \\
(\mathrm{ng} / \mathrm{mL})\end{array}$ & 321 & 463 & 290 & 289 & 68.9 & 0.23 \\
\hline SOD & $25.7^{c}$ & $28.7^{b}$ & $29.8^{\mathrm{b}}$ & $31.5^{\mathrm{a}}$ & 0.45 & $<0.01$ \\
\hline MDA (nmol/mL) & 2.57 & 2.12 & 2.10 & 1.35 & 0.33 & 0.07 \\
\hline
\end{tabular}

$a, b, c$ Means with various letters within the similar row indicate substantial difference. CONT=Chicks received corn-soybean-based diet without additive, BACI=Chicks received corn-soybean-based diet supplemented with $0.1 \%$ zinc bacitracin, FERM $=$ Chicks received diet containing $20 \%$ of the FCPMO, FERB=Chicks received diet containing $20 \%$ of the FCPMO and supplemented with $0.1 \%$ probiotic $B$. subtilis, $\mathrm{SE}=\mathrm{Standard}$ error, IBDV $=$ Infectious bursal disease vaccine, NDV $=$ Newcastle disease vaccine, GMT=geometric mean titer, $\mathrm{SOD}=$ Serum superoxide dismutase, MDA=Malondialdehyde, B. subtilis=Bacillus subtilis

NDV titers (Table-3). With regard particularly to the NDV titer, feeding diets containing either zinc bacitracin, FCPMO, or FCPMO plus B. subtilis were associated with the more protected chickens from ND. Allan and Gough [17] formerly pointed out that HI titers below than $3 \log _{2}$ GMT are suggested as negative (not protected) for typical immunity toward ND. Data on the antioxidative status of broilers are listed in Table3. Compared to CONT, the chicks in BACI, FERM, and FERB groups had higher $(p<0.05)$ SOD activity. SOD has been noted as the first-line defense and most powerful antioxidants in the body of animals [18]. The higher SOD activity in the BACI, FERM, and FERB may, therefore, represent the less oxidative stress and hence less metabolic disorder in the respective birds when compared with the control. Corresponding to our data, the former study reported the increased SOD level in broiler chickens with zinc bacitracin supplementation [19]. In the previous report, we documented the antioxidant potentials of the filamentous fungus C. crassa $[12,15]$. In this respect, fermentation using the latter fungus may implicate in higher antioxidant potentials of the FCPMO resulting in the improved antioxidative status of broilers [9]. In addition to this, the antioxidant potential of $M$. oleifera leaf [11] seemed also to contribute to the improved antioxidant status of broiler chickens. With regard particularly to FERB, the birds from this group showed the highest SOD level in the current work. In addition to the antioxidative effects of fermented feed, C. crassa and $M$. oleifera leaf, the administration of probiotic $B$. subtilis may further corroborate the antioxidative defenses of FERB broilers as reflected by the SOD level. This was supported by the fact that feeding probiotic $B$. subtilis resulted in improved antioxidative status of broilers in the study of Abramowicz et al. [20]. In contrast to SOD 
levels, the serum level of MDA tended $(p=0.07)$ to be lower in BACI, FERM, and FERB than that in CONT birds in the current study. MDA is one of the biomarkers of oxidative stress, at which the lower MDA level implies in the better antioxidative status of broilers. It was most likely that the antioxidative properties of fermented feed, the fungus $C$. crassa, M. oleifera leaf, as well as probiotic $B$. subtilis improved the antioxidant responses resulting in less oxidative damage in broilers.

Data on the blood profile of broilers are provided in Table-4. It was clear that chickens in the BACI and FERM groups had lower $(\mathrm{p}<0.05)$ leukocytes and lymphocytes numbers as compared particularly to the chickens in CONT group. A former study by Hidanah et al. [21] noticed the increased leukocytes and lymphocytes numbers following Mycoplasma gallisepticum infection. Similarly, Akhtar et al. [22] reported that infection with mixed Eimeria species increased the numbers of leukocytes and lymphocytes in broiler chickens. For these reasons, we may infer that the lower counts of leukocytes and lymphocytes in BACI and FERM birds seemed to be associated with the lower potential of infections in these respective birds. This seemed reasonable given that zinc bacitracin and fermented feed possessed the antimicrobial properties, which are possible to control the invading pathogenic microorganisms [10]. It has generally been known that infections may be linked to the increased metabolic rate in animals due to the increased need for maintenance (recovery) energy

Table-4: Complete blood counts of broiler chickens fed treatment diets.

\begin{tabular}{|c|c|c|c|c|c|c|}
\hline \multirow[t]{2}{*}{ Items } & \multicolumn{4}{|c|}{ Dietary groups } & \multirow[t]{2}{*}{ SE } & \multirow[t]{2}{*}{ p-value } \\
\hline & CONT & BACI & FERM & FERB & & \\
\hline $\begin{array}{l}\text { Leukocytes } \\
\left(10^{3} / \mu \mathrm{L}\right)\end{array}$ & $69.8^{a}$ & $59.2^{b}$ & $58.9^{b}$ & $65.9^{a, b}$ & 2.61 & 0.01 \\
\hline $\begin{array}{l}\text { eterophils } \\
\left.10^{3} / \mu \mathrm{L}\right)\end{array}$ & 2.22 & 2.15 & 2.45 & 2.30 & 0.40 & 0.95 \\
\hline cytes & $67.6^{a}$ & $57.0^{\mathrm{b}, \mathrm{c}}$ & $56.4^{c}$ & $63.8^{a, b}$ & 2.46 & 0.01 \\
\hline $\begin{array}{l}\text { mbocytes } \\
\mu L)\end{array}$ & 12.3 & 10.4 & 10.3 & 10.7 & 1.64 & 0.79 \\
\hline $\begin{array}{l}\text { emoglobin } \\
g / d L)\end{array}$ & $9.61^{a}$ & $8.05^{b}$ & $7.45^{\mathrm{b}}$ & $9.56^{a}$ & 0.43 & $<0.01$ \\
\hline $\begin{array}{l}\text { rythrocytes } \\
\left.10^{6} / \mu \mathrm{L}\right)\end{array}$ & $2.78^{a}$ & $2.36^{b}$ & $2.16^{b}$ & $2.76^{a}$ & 0.11 & $<0.01$ \\
\hline $\begin{array}{l}\text { Hematocrit } \\
(\%)\end{array}$ & $34.9^{a}$ & $29.3^{\mathrm{b}}$ & $26.7^{b}$ & $34.6^{a}$ & 1.53 & $<0.01$ \\
\hline MCV (fL) & & & & & 0.98 & \\
\hline & $34.1^{\mathrm{a}}$ & $34.1^{\mathrm{a}}$ & $31.3^{b}$ & $34.6^{a}$ & 0.69 & $<0.01$ \\
\hline $\mathrm{MCHC}(\mathrm{g} / \mathrm{dL})$ & 27.1 & 27.5 & 27.5 & 27.6 & 0.51 & 0.90 \\
\hline
\end{tabular}

$\mathrm{a}, \mathrm{b}$ Means with various letters within the similar row indicate substantial difference. CONT $=$ Chicks received corn-soybean-based diet without additive, BACI=Chicks received corn-soybean-based diet supplemented with $0.1 \%$ zinc bacitracin, FERM $=$ Chicks received diet containing $20 \%$ of the FCPMO, FERB=Chicks received diet containing $20 \%$ of the FCPMO and supplemented with $0.1 \%$ probiotic $B$. subtilis, $\mathrm{SE}=$ Standard error, $\mathrm{MCV}=$ Mean corpuscular volume, $\mathrm{MCH}=$ Mean corpuscular hemoglobin, $\mathrm{MCHC}=$ Mean corpuscular hemoglobin concentration, B. subtilis=Bacillus subtilis
[23]. In this study, the hemoglobin, erythrocytes, and hematocrit values were lower $(p<0.05)$ in BACI and FERM than that in CONT and FERB chickens. Due to the role of erythrocytes in transporting oxygen, and thus supporting the energy-generating metabolism, the higher levels of hemoglobin, erythrocytes, and hematocrit in the CONT and FERB chicks may, therefore, be associated with the higher potential of infections in these chickens. Nonetheless, the latter inference should be taken with care, as the values of hemoglobin and erythrocytes found in this current study were still in the normal ranges. Talebi et al. [24] suggested that healthy broilers have around $2.84 \times 10^{6} / \mu \mathrm{L}$ erythrocytes and $13.94 \mathrm{~g} / \mathrm{dL}$ hemoglobin.

Data on the serum biochemical parameters of broiler chickens are presented in Table-5. The level of serum total triglyceride was lower $(p<0.05)$ in FERM and FERB than that in CONT broilers. Similar to our findings, Yamamoto et al. [25] revealed that feeding Koji-feed (fermented distillery by-product) resulted in decreased concentration of plasma triglyceride in broilers. It seemed that fermented feed enhanced the hydrolysis of triglycerides as well as fatty acid $\beta$-oxidation leading to reduced triglyceride concentrations in the circulatory system of broilers [10]. It was observed in this study that the FERM and FERB chicks had a higher $(p<0.05)$ level of albumin in the serum. Besides

Table-5: Serum biochemical parameters of broiler chickens fed treatment diets.

\begin{tabular}{|c|c|c|c|c|c|c|}
\hline \multirow[t]{2}{*}{ Items } & \multicolumn{4}{|c|}{ Dietary groups } & \multirow[t]{2}{*}{ SE } & \multirow[t]{2}{*}{ p-value } \\
\hline & CONT & BACI & FERM & FERB & & \\
\hline $\begin{array}{l}\text { tal } \\
\text { nolesterol } \\
\mathrm{ng} / \mathrm{dL} \text { ) }\end{array}$ & & & & 101 & 6.44 & 0.16 \\
\hline$g / d L)$ & 93.9 & 89.4 & 86.2 & 85.2 & 5.96 & 0.73 \\
\hline & & & & & & \\
\hline $\begin{array}{l}\text { iglyceride } \\
\text { ng/dL) }\end{array}$ & $50.0^{\mathrm{a}}$ & $\mathrm{b}$ & & $35.2^{b}$ & 3.51 & \\
\hline & & & & & & \\
\hline & & & & & & \\
\hline in & & & & & 0.04 & \\
\hline protein & $2.15^{\mathrm{b}}$ & $.35^{\mathrm{a}, \mathrm{b}}$ & $2.47^{a}$ & $2.21^{\mathrm{b}}$ & 0.08 & 0.03 \\
\hline $\begin{array}{l}\text { obulin } \\
\text { /dL) }\end{array}$ & $0.99^{a, b}$ & $1.18^{\mathrm{a}}$ & $1.07^{\mathrm{a}, \mathrm{b}}$ & $0.92^{\mathrm{b}}$ & 0.07 & 0.03 \\
\hline & 4.08 & 3.66 & 4.22 & 3.17 & 0.32 & 0.07 \\
\hline $\begin{array}{l}\text { Creatinine } \\
\text { (mg/dL) }\end{array}$ & 0.01 & 0.03 & 0.03 & 0.02 & 0.01 & 0.52 \\
\hline \multicolumn{7}{|c|}{$\begin{array}{l}\text { a,bMeans with various letters within the similar row } \\
\text { indicate substantial difference. CONT=Chicks received } \\
\text { corn-soybean-based diet without additive, BACI=Chicks } \\
\text { received corn-soybean-based diet supplemented with } \\
0.1 \% \text { zinc bacitracin, FERM=Chicks received diet } \\
\text { containing } 20 \% \text { of the FCPMO, FERB=Chicks received } \\
\text { diet containing } 20 \% \text { of the FCPMO and supplemented } \\
\text { with } 0.1 \% \text { probiotic } B \text {. subtilis, SE=Standard } \\
\text { error, HDL=High-density lipoprotein cholesterol, } \\
\text { LDL=Low-density lipoprotein cholesterol, AST=Aspartate } \\
\text { aminotransferase, ALT=Alanine aminotransferase. } \\
\text { B. subtilis=Bacillus subtilis }\end{array}$} \\
\hline
\end{tabular}


helping in maintaining the metabolic balances, albumin has been suggested to contribute to tissue protein synthesis in broiler chickens. In this study, the higher level of albumin in FERM and FERB chicks was inversely associated with the level of triglycerides in the serum of the respective birds. The latter condition may suggest that feeding fermented feed shifted the metabolic process from fat synthesis to fatty acid $\beta$-oxidation and tissue protein synthesis. In agreement with our inference, Vieira et al. [26] reported the inverse relationship between serum albumin and triglycerides levels in broilers fed mango waste meal at 42 days of age. However, our inference must be taken with care as the increased albumin level was not capable of increasing the total protein in the serum of the respective birds. The same condition was actually found in the study of Vieira et al. [26], in which the albumin level was not in parallel with the total protein levels in the serum of broilers. Our present finding showed that serum globulin level was lower $(p<0.05)$ in FERB than that in BACI, but did not differ from that in CONT and FERM broilers. In broilers, the globulin level is generally elevated in response to potential infections [27]. In this study, the intestinal populations of coliform, lactose-negative-enterobacteria, as well as enterobacteria were lower in FERB than that in other treatment birds. The lower intestinal pathogenic bacteria load could, therefore, be attributed to the less immune inducement and thus lower serum globulin level. In line with our inference, Manafi et al. [28] noticed that the lower loads of coliforms, Salmonella, and Escherichia coli in the intestine of broilers were associated with the lower level of serum globulin of broilers.

Data on the selected ileal bacterial counts of broilers are presented in Table-6. As previously mentioned, the numbers of coliform, lactose-negative-enterobacteria, and enterobacteria were lower $(p<0.05)$ in FERB than that in other dietary groups. It seemed that the probiotic activities of $B$. subtilis played a substantial role in reducing the numbers of the potential pathogenic bacteria in the ileal digesta of broilers in the current work. The same effect of probiotic $B$. subtilis in reducing the pathogenic bacterial load in broiler intestine has also formerly been reported by Manafi et al. [28]. The present finding, however, partly differed from Manafi et al. [28], as the treatment with antibiotic zinc bacitracin did not reduce the numbers of pathogenic bacteria in the ileum of broiler in the present work. Recently, Sugiharto and Ranjitkar [10] suggested that fermented feed may be a tool to reduce the pathogenic bacteria in the intestine of broilers. However, fermented feed did not markedly influence the number of intestinal bacteria of broilers in the present study. The differences in the nature of raw feed ingredients, microorganisms used as a fermentation starter and the conditions of the experiment may account for the discrepancy above.

In comparison with other groups, the crypt was deeper $(\mathrm{p}<0.05)$ in FERM group in the present study, while the villi height was not significantly different across the dietary groups (Table-7). The corresponding results were actually revealed by Naji et al. [29], in which feeding fermented feed increased CD in the whole intestinal segments (duodenum, jejunum, and ileum) of broiler chickens. In contrast to our data, the increased $\mathrm{CD}$ in the latter study did not lower the ratio of villus height to $\mathrm{CD}(\mathrm{VH} / \mathrm{CD})$ in the intestine of the respective broilers. In most circumstances, the higher $\mathrm{VH} / \mathrm{CD}$ may indicate the better digestion and absorption capacity of the small intestine of broilers. The lower $\mathrm{VH} / \mathrm{CD}$ in the duodenum of broiler in the present study may, therefore, reduce the absorptive capacity of chickens. The definite reason for the deeper crypt and hence lower VH/CD in FERM birds remains unknown, but the higher fiber content in the FERM diet seemed to be responsible. A recent study by Saadatmand et al. [30] showed that dietary fiber (rice hull) was attributed to the lower $\mathrm{VH} / \mathrm{CD}$ in the jejunum and ileum resulting in weak absorptive capacity and impaired growth performance of broiler chickens. With regard to FERB birds, the detrimental

Table-6: Ileal bacterial populations of broiler chickens fed treatment diets.

\begin{tabular}{lcccccc}
\hline \multirow{2}{*}{$\begin{array}{l}\text { Items } \\
\text { (log CFU/g) }\end{array}$} & \multicolumn{4}{c}{ Dietary groups } & SE & p-value \\
\cline { 2 - 5 } & CONT BACI FERM & FERB & & \\
\hline LAB & 11.4 & 11.3 & 11.4 & 11.2 & 0.10 & 0.24 \\
Coliform & $9.30^{\mathrm{a}}$ & $9.41^{\mathrm{a}}$ & $8.82^{\mathrm{a}}$ & $8.09^{\mathrm{b}}$ & 0.19 & $<0.01$ \\
Lactose- & $9.01^{\mathrm{a}}$ & $8.99^{\mathrm{a}}$ & $9.25^{\mathrm{a}}$ & $8.36^{\mathrm{b}}$ & 0.19 & 0.02 \\
negative & & & & & & \\
-enterobacteria & & & & & & \\
Enterobacteria & $9.54^{\mathrm{a}}$ & $9.59^{\mathrm{a}}$ & $9.42^{\mathrm{a}}$ & $8.72^{\mathrm{b}}$ & 0.17 & $<0.01$ \\
\hline
\end{tabular}

$a, b$ Means with various letters within the similar row indicate substantial difference. $\mathrm{CONT}=\mathrm{Chicks}$ received corn-soybean-based diet without additive, BACI=Chicks received corn-soybean-based diet supplemented with $0.1 \%$ zinc bacitracin, FERM $=$ Chicks received diet containing $20 \%$ of the FCPMO, FERB=Chicks received diet containing $20 \%$ of the FCPMO and supplemented with $0.1 \%$ probiotic $B$. subtilis, $\mathrm{SE}=$ Standard error, $\mathrm{LAB}=$ Lactic acid bacteria, $\mathrm{CFU}=$ Colony-forming unit, B. subtilis=Bacillus subtilis

Table-7: Duodenal morphology of broiler chickens fed treatment diets.

\begin{tabular}{lcccccc}
\hline Items & \multicolumn{4}{c}{ Dietary groups } & SE & p-value \\
\cline { 2 - 5 } & CONT & BACI & FERM & FERB & & \\
\hline $\begin{array}{l}\text { Villi } \\
\text { height }(\mu \mathrm{m})\end{array}$ & 1355 & 1352 & 1476 & 1491 & 71.5 & 0.36 \\
$\begin{array}{l}\text { Crypt } \\
\text { depth }(\mu \mathrm{m})\end{array}$ & $211^{\mathrm{b}}$ & $252^{\mathrm{b}}$ & $368^{\mathrm{a}}$ & $254^{\mathrm{b}}$ & 27.1 & $<0.01$ \\
VH/CD & $6.60^{\mathrm{a}}$ & $5.54^{\mathrm{a}, \mathrm{b}}$ & $4.54^{\mathrm{b}}$ & $6.09^{\mathrm{a}}$ & 0.49 & 0.03 \\
\hline
\end{tabular}

$a, b$ Means with various letters within the similar row indicate substantial difference. CONT=Chicks received corn-soybean-based diet without additive, BACI=Chicks received corn-soybean-based diet supplemented with $0.1 \%$ zinc bacitracin, FERM $=$ Chicks received diet containing $20 \%$ of the FCPMO, FERB=Chicks received diet containing $20 \%$ of the FCPMO and supplemented with $0.1 \%$ probiotic $B$. subtilis, $\mathrm{SE}=$ Standard error, $\mathrm{VH} / \mathrm{CD}=\mathrm{Villi}$ height to crypt depth ratio, $B$. subtilis=Bacillus subtilis 
Table-8: Short chains fatty acids concentrations in caecum of broiler chickens fed treatment diets.

\begin{tabular}{lcccccc}
\hline \multirow{2}{*}{$\begin{array}{l}\text { Items } \\
\mathbf{m m o l} / \mathbf{k g})\end{array}$} & \multicolumn{4}{c}{ Dietary groups } & \multirow{2}{*}{ SE } & p-value \\
\cline { 2 - 5 } & CONT & BACI & FERM & FERB & & \\
\hline Acetic acid & 155 & 112 & 131 & 193 & 33.4 & 0.37 \\
Propionic acid & 44.8 & 34.3 & 43.6 & 71.0 & 12.4 & 0.20 \\
Butyric acid & 46.5 & 36.9 & 40.5 & 67.6 & 11.6 & 0.26 \\
\hline
\end{tabular}

CONT $=$ Chicks received corn-soybean-based diet without additive, $\mathrm{BACI}=$ Chicks received corn-soybean-based diet supplemented with $0.1 \%$ zinc bacitracin,

FERM $=$ Chicks received diet containing $20 \%$ of the FCPMO, FERB $=$ Chicks received diet containing $20 \%$ of the FCPMO and supplemented with $0.1 \%$ probiotic $B$. subtilis,

$\mathrm{SE}=$ Standard error, $B$. subtilis=Bacillus subtilis

effect of dietary fiber on the intestinal morphology seemed to be compensated by the presence of probiotic $B$. subtilis, which has been documented to increase the $\mathrm{VH}$, decrease $\mathrm{CD}$, and thus increase $\mathrm{VH} / \mathrm{CD}$ [28].

Data in our current study (Table-8) showed no substantial effect of treatments on the production of SCFA in the cecal digesta of broilers. In accordance with this finding, Sharma et al. [27] showed that feeding crimped kernel maize silage did not affect the production of SCFA in the ileum and cecum of broilers. In contrast to both studies, our previous work revealed that feeding Acremonium charticola-fermented cassava pulp resulted in greater production of butyric acid in the cecal digesta of broiler chickens [31]. Possibly, the different nature and nutritional qualities of the fermented products, the composition of the complete rations and the conditions of the studies were account for the divergent findings above.

\section{Conclusion}

Feeding FCPMO improved immune responses, antioxidative status, and physiological conditions, but had minimum impact on the intestinal ecology of broilers.

\section{Authors' Contributions}

SS designed, conducted the experiment, and prepared the manuscript, EW, TY, TAS, and HIW conducted the in vivo experiment and revised the manuscript and II conducted the data analysis and revised the manuscript. All authors read and approved the final manuscript.

\section{Acknowledgments}

The experiment was funded by Diponegoro University, Indonesia through non-tax state revenue no.385-83/UN7.P4.3/PP/2019.

\section{Competing Interests}

The authors declare that they have no competing interests.

\section{Publisher's Note}

Veterinary World remains neutral with regard to jurisdictional claims in published institutional affiliation.

\section{References}

1. Ahiwe, E.U., Omede, A.A., Abdallh, M.B. and Iji, P.A. (2018) Managing Dietary Energy Intake by Broiler Chickens to Reduce Production Costs and Improve Product Quality. IntechOpen, London.

2. Khempaka, S., Molee, W. and Guillaume, M. (2009) Dried cassava pulp as an alternative feedstuff for broilers: Effect on growth performance, carcass traits, digestive organs, and nutrient digestibility. J. Appl. Poult. Res., 18(3): 487-493.

3. Sugiharto, S., Yudiarti, T., Isroli, I. and Widiastuti, E. (2018) The potential of tropical agro-industrial by-products as a functional feed for poultry. Iran. J. Appl. Anim. Sci., 8(3): 375-385.

4. Sugiharto, S. (2019) A review on fungal fermented cassava pulp as a cheap alternative feedstuff in poultry ration. J. Worlds Poult. Res., 9(1): 1-6.

5. Khempaka, S., Thongkratok, R., Okrathok, S. and Molee, W. (2014) An evaluation of cassava pulp feedstuff fermented with $A$. oryzae, on growth performance, nutrient digestibility and carcass quality of broilers. J. Poult. Sci., 51(1): 71-79.

6. Sugiharto, S., Yudiarti, T. and Isroli, I. (2016) Haematological and biochemical parameters of broilers fed cassava pulp fermented with filamentous fungi isolated from the Indonesian fermented dried cassava. Livest. Res. Rural Dev., 28(4): 1-17.

7. Shahzad, M.N., Javed, M.T., Shabir, S., Irfan, M. and Hussain, R. (2012) Effects of feeding urea and copper sulphate in different combinations on live body weight, carcass weight, percent weight to body weight of different organs and histopathological tissue changes in broilers. Exp. Toxicol. Pathol., 64(3): 141-147.

8. Sugiharto, S., Yudiarti, T., Isroli, I., Widiastuti, E., Wahyuni, H.I. and Sartono, T.A. (2019) Recent advances in the incorporation of leaf meals in broiler diets. Livest. Res. Rural Dev., 31(7). http://www.lrrd.org/lrrd31/7/sgu_ u31109.html. Last accessed on 21-02-2020.

9. Hu, Y., Wang, Y., Li, A., Wang, Z., Zhang, X., Yun, T., Qiu, L. and Yin, Y. (2016) Effects of fermented rapeseed meal on antioxidant functions, serum biochemical parameters and intestinal morphology in broilers. Food Agric. Immunol., 27(2): 182-193.

10. Sugiharto, S. and Ranjitkar, S. (2019) Recent advances in fermented feeds towards improved broiler chicken performance, gastrointestinal tract microecology and immune responses: A review. Anim. Nutr., 5(1): 1-10.

11. Gopalakrishnan, L., Doriyaa, K. and Kumar, D.S. (2016) Moringa oleifera: A review on nutritive importance and its medicinal application. Food Sci. Human Wellness, 5(2): 49-56.

12. Sugiharto, S. (2019) A review of filamentous fungi in broiler production. Ann. Agric. Sci., 64(1): 1-8.

13. Sugiharto, S., Isroli, I., Yudiarti, T., Widiastuti, E., Wahyuni, H.I. and Sartono, T.A. (2018) Effect of two-step fermentation by Chrysonilia crassa and Bacillus subtilis on nutritional values and antioxidative properties of agro-industrial by-products as poultry feed ingredients. J. Adv. Vet. Anim. Res., 5(4): 472-480.

14. AOAC. (1995) Official Methods of Analysis of the Association of Analytical Chemists. AOAC, Washington DC, USA.

15. Sugiharto, S., Yudiarti, T., Isroli, I., Widiastuti, E. and Putra, F.D. (2017) Effect of dietary supplementation with Rhizopus oryzae or Chrysonilia crassa on growth performance, blood profile, intestinal microbial population, and carcass traits in broilers exposed to heat stress. Arch. Anim. Breed., 60(3): 347-356.

16. Sugiharto, S., Lauridsen, C. and Jensen, B.B. (2015) Gastrointestinal ecosystem and immunological responses in E. coli challenged pigs after weaning fed liquid diets containing whey permeate fermented with different lactic acid 
bacteria. Anim. Feed Sci. Technol., 207 (2015): 278-282.

17. Allan, W.H. and Gough, R.E. (1974) A standard haemagglutination inhibition test for Newcastle disease. (1). A comparison of macro and micro methods. Vet. Rec., 95(6): $120-123$

18. Ighodaro, O.M. and Akinloye, O.A. (2018) First line defence antioxidants-superoxide dismutase (SOD), catalase (CAT) and glutathione peroxidase (GPX): Their fundamental role in the entire antioxidant defence grid. Alexandria $J$. Med., 54(4): 287-293.

19. Ismail, I.B., Al-Busadah, K.A. and El-Bahr, S.M. (2013) Oxidative stress biomarkers and biochemical profile in broilers chicken fed zinc bacitracin and ascorbic acid under hot climate. Am. J. Biochem. Mol. Biol., 3(2): 202-214.

20. Abramowicz, K., Krauze, M. and Ognik, K. (2019) The effect of a probiotic preparation containing Bacillus subtilis PB6 in the diet of chickens on redox and biochemical parameters in their blood. Ann. Anim. Sci., 19(2): 433-451.

21. Hidanah, S., Sabdoningrum, E.K., Wahjuni, R.S. and Chusniati, S. (2018) Effects of meniran (Phyllanthus niruri L.) administration on leukocyte profile of broiler chickens infected with Mycoplasma gallisepticum. Vet. World, 11(6): 834-839.

22. Akhtar, M., Awais, M.M., Anwar, M.I., Ehtisham-ulHaque, S., Nasir, A., Saleemi, M.K. and Ashraf, K. (2015) The effect of infection with mixed Eimeria species on hematology and immune responses following Newcastle disease and infectious bursal disease booster vaccination in broilers. Vet. $Q .$, 35(1): 21-26.

23. Kostadinović, L.M., Pavkov, S.T., Lević, J.D., GalonjaCoghill, T.A., Dozet, G.K. and Bojat, N.Č. (2011) Effect of sulphachloropyrazine on antioxidative systems in blood and liver of broilers. Acta Vet. Brno, 80(2): 165-170.

24. Talebi, A., Asri-Rezaei, S., Rozeh-Chai, R. and Sahraei, R. (2005) Comparative studies on haematological values of broiler strains (Ross, Cobb, Arbor-acres and Arian). Int. J.
Poult. Sci., 4(8): 573-579.

25. Yamamoto, M., Saleh, F., Tahir, M., Ohtsuka, A. and Hayashi, K. (2007) The effect of koji-feed (fermented distillery by-product) on the growth performance and nutrient metabolizability in broiler. J. Poult. Sci., 44(3): 291-296.

26. Vieira, P.A.F., Souza, C.S., de Almeida Barbosa, A., D'Ávila Lima, H.J., Fontes, E.A.F., Vieira, B.C., de Almeida Oliveira, M.G., de Moraes, G.H.K., de Queiroz, J.H. and Albino, L.F.T. (2016) Serum lipid profile of broilers fed diets with inclusion of mango waste meal. Semina, 37(5): 3327-3334

27. Sharma, N., Ranjitkar, S., Sharma, N.K. and Engberg, R.M. (2017) Influence of feeding crimped kernel maize silage on the course of subclinical necrotic enteritis in a broiler disease model. Anim. Nutr., 3(4): 392-398.

28. Manafi, M., Khalaji, S., Hedayati, M. and Pirany, N. (2017) Efficacy of Bacillus subtilis and bacitracin methylene disalicylate on growth performance, digestibility, blood metabolites, immunity, and intestinal microbiota after intramuscular inoculation with Escherichia coli in broilers. Poult. Sci., 96(5): 1174-1183.

29. Naji, S.A., Al-Gharawi, J.K.M., Jawad, H.S.A., Lokman, I.H. and Al-Zamili, I.F.B. (2017) Effects of moist and fermented feed with probiotic displacement levels in broiler nutrition on morphology and histology of the intestine. Transylvanian Rev., 25(18): 4786-4792.

30. Saadatmand, N., Toghyani, M. and Gheisari, A. (2019) Effects of dietary fiber and threonine on performance, intestinal morphology and immune responses in broiler chickens. Anim. Nutr., 5(3): 248-255.

31. Sugiharto, S., Yudiarti, T., Isroli, I., Widiastuti, E. and Putra, F.D. (2017) Effects of feeding cassava pulp fermented with Acremonium charticola on growth performance, nutrient digestibility and meat quality of broiler chicks. S. Afr. J. Anim. Sci., 47(2): 130-139. 